\title{
Prevalence of Amyloidosis in Korea
}

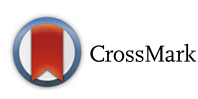

\author{
Su Ra Seo ${ }^{1,2}$, Shin Yi Jang ${ }^{3^{*}}$ D, Ga Yeon Lee ${ }^{3}$, Bareun Choi ${ }^{4}$, Heeran Chun ${ }^{5}$, Eun Jeong Cho ${ }^{6}$ and Sung-il Cho ${ }^{1}$
}

\begin{abstract}
Background: The aim of this study was to assess in amyloidosis prevalence in Korea between 2006 and 2015.

Methods: Primary diagnoses related to amyloidosis, regardless of subtype, were collected from the Korean National Health Insurance Service from 2006 through 2015.

Results: Overall, the age-standardized prevalence of amyloidosis was 0.93 (95\% confidence interval (Cl) 0.81, 1.04) persons per 100,000 persons in 2006 and $1.91(95 \% \mathrm{Cl} 1.78,2.05)$ persons per 100,000 persons in 2015. This included an increase from $0.43(95 \% \mathrm{Cl} 0.35,0.51)$ to $1.04(95 \% \mathrm{Cl} 0.94,1.14)$ persons per 100,000 persons in men and from 0. $49(95 \% \mathrm{Cl} 0.40,0.57)$ to $0.87(95 \% \mathrm{Cl} 0.77,0.96)$ persons per 100,000 persons in women. In particular, the agestandardized prevalence of amyloidosis showed a greater increase in patients aged 65 years or older and in patients aged 45-64 years than in patients aged 20-44 years, for both men and women.

Conclusions: The overall age-standardized prevalence of amyloidosis was approximately 2 persons per 100,000 persons in 2015. The overall age-standardized prevalence of amyloidosis increased between 2006 and 2015, especially in individuals aged 45-64 and older than 65 years.
\end{abstract}

Keywords: Prevalence, Amyloidosis, Korea

\section{Background}

Amyloidosis is a rare disease that can cause systemic dysfunction and abnormal fibrillar protein deposits in the extracellular space, resulting in impaired function of various organs. The kidney and heart are most commonly involved, but the nerves and gastrointestinal tract can also be affected [1-4]. Cardiac involvement is the major determinant of prognosis in amyloidosis patients [5]. The subtypes of amyloidosis are determined by the biochemical properties of the progenitor proteins that form the deposited fibers. These subtypes require very different treatment methods [6]. Therefore, determining the correct amyloidosis subtype is important. Diagnosis of amyloidosis requires tissue biopsy, which is assessed for evidence of characteristic amyloid deposits using treatment with various stains [7]. The major systemic types of amyloidosis are AL, which is associated with light chain-producing plasma cell dyscrasia; AA, which is associated with longstanding inflammation; wild-type ATTR, which is associated with normal transthyretin

\footnotetext{
* Correspondence: bautai@hanmail.net

${ }^{3}$ Division of Cardiology, Department of Medicine, Imaging Center, Heart Vascular Stroke Institute, Samsung Medical Center, Sungkyunkwan University School of Medicine, Seoul 06351, Republic of Korea

Full list of author information is available at the end of the article
}

and old age; and hereditary ATTR, which is associated with a transthyretin mutation [1]. Half of patients with familial amyloidosis have been shown to have no family history of the disease [8]. If amyloidosis is not treated properly, it has a negative prognosis such as a low survival rate. We analyzed changes in the age-adjusted prevalence of amyloidosis in Korea from 2006 through 2015. We hope that these basic data will be used to improve the quality of life and to extend lives of amyloidosis patients through successful intervention following earlier diagnosis [9].

\section{Methods}

\section{Study population}

Data were collected from Korean National Health Insurance (KNHI) benefit records from 2006 until 2015. The KNHI provides compulsory social insurance in the form of employee medical insurance and self-employed medical insurance that covers approximately $98 \%$ of the people living in the country. Enrollment in KNHI is enforced for all citizens, and enrollees are obligated to pay insurance premiums assessed based on income level. Regardless of the level of insurance premiums, KNHI 
benefits are paid evenly under the relevant laws and regulations. Medical Aid targets low-income recipients under the National Basic Livelihood Security Act and covers about $2 \%$ of the total population [10]. We excluded records from the Medical Aid branch of the National Health Insurance Service. We analyzed records of primary diagnoses related to amyloidosis using the following 10th revision of the International Statistical Classification of Diseases and Related Health Problems (ICD 10) codes regardless of subtype: E85.0 Non-neuropathic heredofamilial amyloidosis; E85.1 Neuropathic heredofamilial amyloidosis; E85.2 Heredofamilial amyloidosis, unspecified; E85.3 Secondary systemic amyloidosis; E85.4 Organ-limited amyloidosis; E85.8 Other amyloidosis; and E85.9 Amyloidosis, unspecified.

\section{Statistical methods}

The age-standardized prevalence of amyloidosis was calculated with the direct method [11] using the beneficiaries of health insurance from the Korean National Health Insurance Statistical Yearbook from 2006 through 2015 [12-21] and the estimated Korean population in 2015 [22] as a reference [23, 24].

\section{Results}

Overall, the age-standardized prevalence of amyloidosis was 0.93 persons per 100,000 persons in 2006 and 1.91 persons per 100,000 persons in 2015. This included an increase from 0.43 to 1.04 persons per 100,000 persons in men and from 0.49 to 0.87 persons per 100,000 persons in women. For males in 2006, the prevalence of amyloidosis per 100,000 persons was 0.14 persons aged 20-44 years, 0.37 persons aged 45-64 years, and 1.06 persons older than 65 years. For males in 2015, the prevalence of amyloidosis per 100,000 persons was 0.29 persons aged 20-44 years, 1.18 persons aged 4564 years, and 2.90 persons older than 65 years. For females in 2006, the prevalence of amyloidosis per 100,000 persons was 0.13 persons aged $20-44$ years, 0.58 persons aged 45-64 years, and 0.97 persons older than 65 years. For females in 2015, the prevalence of amyloidosis per 100,000 persons was 0.23 persons aged 20-44 years, 1.16 persons aged 45-64 years, and 2.02 persons older than 65 years (Table 1 ).

\section{Discussion}

Our results demonstrate that the overall agestandardized prevalence of amyloidosis in 2015 was approximately 2 persons per 100,000 persons in Korea. Also, the overall age-standardized prevalence of amyloidosis increased between 2006 and 2015 in patients over 45 years of age. Few studies have reported the overall age-standardized prevalence of amyloidosis. Therefore, the results in this study cannot be compared to those of other geographic or ethnic groups. Nevertheless, the results of the present study are similar to those of earlier studies. The estimated minimum prevalence of systemic amyloidosis in the United Kingdom is 20 persons per one million [25]. In our study, the agestandardized prevalence of amyloidosis showed a greater increase in patients aged 65 years or older and those aged 45-64 years than it did in patients aged 20-44 years for both men and women. Thus, our results indicate that amyloidosis tends to affect older people. This result is consistent with previous reports from the National Organization for Rare Disorders. Approximately 4000 new persons are diagnosed with AL amyloidosis annually in the United States (U.S.), with symptoms typically diagnosed at age 50-65. Moreover, familial amyloidosis, caused by a transthyretin mutation occurs in approximately 1 of every 100,000 Caucasians in the U.S. and more commonly among African Americans (approximately $4 \%$ in that population). The symptoms usually begin between 40 and 65 years of age [26].

To address potential concerns about the accuracy of the data recorded during the study period, we obtained additional data consisting of main diagnoses that corresponded to National Health Insurance expanded benefit coverage for a rare incurable disease (expanded benefit coverage) as the main diagnosis from 2009. In order to be qualified for the expanded benefit coverage, the amyloidosis should be designated as primary diagnoses. The expanded benefit coverage special number is V121. The expanded benefit coverage policy is applied to patients who have paid $10 \%$ of the total amount of the medical treatment cost for either outpatient or inpatient care for 5 years from the registration date. That is, the National Health Insurance Service renews the expanded benefit coverage qualifications every five years. We also found similar distributions of amyloidosis in the 2015 data from the National Health Insurance Service $(n=771)$ and the 2011 to 2015 National Health Insurance Service expanded benefit coverage $(n=749)$ (Additional file 1: Table S1).

For the further analysis, we calculated the agestandardized prevalence using the direct method with the World Health Organization (WHO) standard population in 2000-2025 [27] as a reference (Additional file 1: Table S2). Overall, the age-standardized prevalence of amyloidosis was 6.92 persons per 100,000 persons in 2006 and 21.1 persons per 100,000 persons in 2015. In other words, using the WHO standard population in 2000-2025 as the reference, the age-standardized prevalence of amyloidosis has tripled during the past decade.

\section{Study limitations}

Our study has several limitations. First, our data included only major amyloidosis and did not consider 
Table 1 Age-adjusted cumulative prevalence ${ }^{a}$ of amyloidosis, both overall and by gender (per 100,000 persons), along with 95\% confidence intervals (Cl)

\begin{tabular}{|c|c|c|c|c|c|c|c|c|c|c|}
\hline \multirow[t]{2}{*}{ Variable } & \multicolumn{2}{|r|}{2006} & \multicolumn{2}{|r|}{2007} & \multicolumn{2}{|r|}{2008} & \multicolumn{2}{|r|}{2009} & \multicolumn{2}{|r|}{2010} \\
\hline & $\mathrm{n}$ & $\begin{array}{c}\text { Prevalence } \\
(95 \% \text { CI) }\end{array}$ & $\mathrm{n}$ & $\begin{array}{c}\text { Prevalence } \\
(95 \% \mathrm{Cl})\end{array}$ & $n$ & $\begin{array}{c}\text { Prevalence } \\
(95 \% \mathrm{Cl})\end{array}$ & $n$ & $\begin{array}{c}\text { Prevalence } \\
(95 \% \mathrm{Cl})\end{array}$ & $\mathrm{n}$ & $\begin{array}{c}\text { Prevalence } \\
(95 \% \mathrm{Cl})\end{array}$ \\
\hline All & 253 & $0.93(0.81,1.04)$ & 334 & $1.17(1.04,1.30)$ & 376 & $1.26(1.13,1.39)$ & 414 & $1.31(1.18,1.44)$ & 424 & $1.30(1.18,1.43)$ \\
\hline 20-44 years old & 58 & $0.28(0.20,0.35)$ & 60 & $0.29(0.21,0.36)$ & 71 & $0.35(0.27,0.43)$ & 87 & $0.43(0.34,0.53)$ & 65 & $0.32(0.24,0.40)$ \\
\hline 45-64 years old & 111 & $0.97(0.79,1.15)$ & 164 & $1.38(1.17,1.59)$ & 169 & $1.37(1.16,1.58)$ & 192 & $1.50(1.29,1.73)$ & 220 & $1.66(1.44,1.89)$ \\
\hline Over 65 years & 84 & $2.05(1.61,2.49)$ & 110 & $2.49(2.02,2.96)$ & 136 & $2.95(2.45,3.45)$ & 135 & $2.78(2.31,3.25)$ & 139 & $2.78(2.32,3.24)$ \\
\hline Men & 118 & $0.43(0.35,0.51)$ & 172 & $0.60(0.51,0.69)$ & 187 & $0.62(0.53,0.71)$ & 231 & $0.73(0.63,0.83)$ & 230 & $0.71(0.61,0.80)$ \\
\hline 20-44 years old & 30 & $0.14(0.09,0.19)$ & 31 & $0.14(0.09,0.20)$ & 39 & $0.19(0.13,0.25)$ & 48 & $0.23(0.16,0.30)$ & 38 & $0.18(0.12,0.25)$ \\
\hline 45-64 years old & 44 & $0.37(0.26,0.49)$ & 82 & $0.69(0.54,0.84)$ & 81 & $0.65(0.51,0.80)$ & 104 & $0.81(0.66,0.97)$ & 108 & $0.81(0.66,0.97)$ \\
\hline Over 65 years & 44 & $1.06(0.74,1.38)$ & 59 & $1.33(0.99,1.68)$ & 67 & $1.44(1.09,1.79)$ & 79 & $1.62(1.26,1.98)$ & 84 & $1.67(1.31,2.03)$ \\
\hline Women & 135 & $0.49(0.40,0.57)$ & 162 & $0.56(0.47,0.65)$ & 189 & $0.63(0.54,0.73)$ & 183 & $0.57(0.49,0.66)$ & 194 & $0.59(0.51,0.68)$ \\
\hline 20-44 years old & 28 & $0.13(0.08,0.18)$ & 29 & $0.14(0.09,0.19)$ & 32 & $0.15(0.09,0.21)$ & 39 & $0.19(0.13,0.25)$ & 27 & $0.13(0.08,0.18)$ \\
\hline 45-64 years old & 67 & $0.58(0.44,0.72)$ & 82 & $0.69(0.54,0.84)$ & 88 & $0.71(0.56,0.86)$ & 88 & $0.69(0.54,0.83)$ & 112 & $0.84(0.68,1.00)$ \\
\hline Over 65 years & 40 & $0.97(0.66,1.27)$ & 51 & $1.15(0.83,1.47)$ & 69 & $1.49(1.13,1.84)$ & 56 & $1.15(0.85,1.46)$ & 55 & $1.09(0.80,1.38)$ \\
\hline \multirow[t]{2}{*}{ Variable } & & 2011 & & 2012 & & 2013 & & 2014 & & 2015 \\
\hline & $\mathrm{n}$ & $\begin{array}{c}\text { Prevalence } \\
(95 \% \text { CI) }\end{array}$ & $n$ & $\begin{array}{c}\text { Prevalence } \\
(95 \% \mathrm{Cl})\end{array}$ & $n$ & $\begin{array}{c}\text { Prevalence } \\
(95 \% \mathrm{Cl})\end{array}$ & $n$ & $\begin{array}{c}\text { Prevalence } \\
(95 \% \mathrm{Cl})\end{array}$ & $n$ & $\begin{array}{c}\text { Prevalence } \\
(95 \% \mathrm{Cl})\end{array}$ \\
\hline All & 454 & $1.35(1.22,1.47)$ & 577 & $1.64(1.50,1.77)$ & 638 & $1.71(1.58,1.85)$ & 725 & $1.86(1.73,2.00)$ & 771 & $1.91(1.78,2.05)$ \\
\hline 20-44 years old & 63 & $0.32(0.24,0.40)$ & 76 & $0.38(0.30,0.47)$ & 90 & $0.46(0.36,0.56)$ & 104 & $0.54(0.43,0.64)$ & 103 & $0.54(0.43,0.64)$ \\
\hline 45-64 years old & 218 & $1.59(1.38,1.80)$ & 269 & $1.92(1.69,2.15)$ & 320 & $2.21(1.97,2.45)$ & 343 & $2.30(2.05,2.54)$ & 361 & $2.35(2.11,2.59)$ \\
\hline Over 65 years & 173 & $3.33(2.83,3.83)$ & 232 & $4.23(3.68,4.77)$ & 228 & $3.95(3.44,4.47)$ & 278 & $4.62(4.08,5.17)$ & 307 & $4.93(4.38,5.48)$ \\
\hline Men & 235 & $0.69(0.60,0.78)$ & 305 & $0.86(0.76,0.95)$ & 355 & $0.95(0.85,1.05)$ & 372 & $0.95(0.86,1.05)$ & 420 & $1.04(0.94,1.14)$ \\
\hline 20-44 years old & 34 & $0.17(0.11,0.23)$ & 48 & $0.24(0.17,0.31)$ & 52 & $0.26(0.19,0.33)$ & 57 & $0.29(0.21,0.37)$ & 57 & $0.29(0.22,0.37)$ \\
\hline 45-64 years old & 106 & $0.77(0.62,0.92)$ & 138 & $0.98(0.81,1.14)$ & 164 & $1.13(0.95,1.30)$ & 169 & $1.13(0.95,1.30)$ & 182 & $1.18(1.01,1.35)$ \\
\hline Over 65 years & 95 & $1.82(1.45,2.19)$ & 119 & $2.16(1.77,2.55)$ & 139 & $2.42(2.01,2.82)$ & 146 & $2.42(2.02,2.81)$ & 181 & $2.90(2.48,3.33)$ \\
\hline Women & 219 & $0.64(0.56,0.73)$ & 272 & $0.77(0.68,0.86)$ & 283 & $0.75(0.66,0.84)$ & 353 & $0.90(0.81,1.00)$ & 351 & $0.87(0.77,0.96)$ \\
\hline 20-44 years old & 29 & $0.14(0.09,0.19)$ & 28 & $0.13(0.08,0.19)$ & 38 & $0.19(0.13,0.25)$ & 47 & $0.24(0.17,0.31)$ & 46 & $0.23(0.16,0.30)$ \\
\hline 45-64 years old & 112 & $0.81(0.66,0.97)$ & 131 & $0.93(0.77,1.09)$ & 156 & $1.07(0.90,1.24)$ & 174 & $1.16(0.99,1.33)$ & 179 & $1.16(0.99,1.33)$ \\
\hline Over 65 years & 78 & $1.49(1.15,1.82)$ & 113 & $2.05(1.67,2.43)$ & 89 & $1.53(1.21,1.85)$ & 132 & $2.19(1.81,2.56)$ & 126 & $2.02(1.67,2.37)$ \\
\hline
\end{tabular}

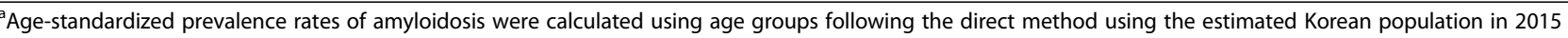
as a reference

other conditions, such as amyloidosis subtype. Furthermore, we used the primary diagnosis based on signs and symptoms, which might differ from the final diagnosis. Thus, the prevalence of amyloidosis in this study might be under- or overestimated. To address this limitation, we compared our results with an analysis of expanded benefit coverage data. However, further collection of nationwide registry data with definite inclusion criteria using specific organ biopsies will be required to confirm amyloidosis. We also carried out an additional analysis for the percentage of each subtype of amyloidosis by ICD 10 code in 2015: E85.0 Non-neuropathic heredofamilial amyloidosis (1.48\%); E85.1 Neuropathic heredofamilial amyloidosis (0.94\%); E85.2 Heredofamilial amyloidosis, unspecified (1.48\%); E85.3 Secondary systemic amyloidosis (0.0\%); E85.4 Organ-limited amyloidosis (25.9\%); E85.8 Other amyloidosis (10.7\%); and E85.9 Amyloidosis, unspecified (59.5\%). Second, the National Health Insurance benefit records might have missed potential patients with amyloidosis who did not use medical services, paid for their own medical expenses, or received Medical Aid. Therefore, because our data indicate that the prevalence of amyloidosis increases with age, a hospitalbased amyloidosis registry is needed in Korea. Third, we considered only age, gender, and year. Our data did not include risk factors for chronic heart or kidney disease, socioeconomic position, or health behavior factors, so we could not adjust the prevalence of amyloidosis for several possible confounding variables. Therefore, a follow-up study is needed to determine the long-term survival rate of patients with amyloidosis after adjusting for confounding variables. 


\section{Conclusions}

We found that the overall age-standardized prevalence of amyloidosis was approximately 2 persons per 100,000 persons in 2015. Our results might have important clinical and public health implications because subjects with amyloidosis tend to be elderly.

\section{Additional file}

Additional file 1: Table S1. New patients with amyloidosis (special numbers for expanded benefit coverage V121) according to National Health Insurance expanded benefit coverage by year. Table S2. Ageadjusted cumulative prevalence ${ }^{a}$ of amyloidosis, both overall and by gender (per 100,000 persons), along with 95\% confidence intervals (CI) using World Health Organization standard population in 2000. (DOC $85 \mathrm{~kb}$ )

\section{Abbreviations}

expanded benefit coverage: National Health Insurance expanded benefit coverage for a rare incurable disease; US: United States; WHO: World Health Organization

\section{Acknowledgements}

Not applicable.

\section{Funding}

Not applicable.

\section{Availability of data and materials}

Availability of data. Data were received from Korean National Health Insurance benefit records from the National Health Insurance Service.

\section{Authors' contributions}

SRS analyzed statistics, discussed interpretations, and wrote this paper. SYJ made the study design, analyzed statistics and discussed interpretations, wrote this paper, and takes all responsibility for this paper. HRC analyzed statistics and discussed interpretations. GYL, BRC, EJC, and SIC discussed interpretations. All authors read and approved the final manuscript.

\section{Ethics approval and consent to participate}

Evaluation of the study protocol was exempted by the Institutional Review Board of Samsung Medical Center (IRB No. 2017-02-032).

\section{Consent for publication}

Not applicable.

\section{Competing interests}

The authors declare that they have no competing interests.

\section{Publisher's Note}

Springer Nature remains neutral with regard to jurisdictional claims in published maps and institutional affiliations.

\footnotetext{
Author details

${ }^{1}$ Graduate School of Public Health, Seoul National University, Seoul 08826, Republic of Korea. ${ }^{2}$ The National Health Insurance Service, Wonju 25234, Republic of Korea. ${ }^{3}$ Division of Cardiology, Department of Medicine, Imaging Center, Heart Vascular Stroke Institute, Samsung Medical Center, Sungkyunkwan University School of Medicine, Seoul 06351, Republic of Korea. ${ }^{4}$ Namyangju Poongyang Public Health Center, Namyangju 12066 Republic of Korea. ${ }^{5}$ Department of Health Administration, Jungwon University, Goesan 28024, Republic of Korea. ${ }^{6}$ Division of Cardiology, Department of Internal Medicine, Cardiology Clinic, National Cancer Center, Goyang 10408, Republic of Korea.
}

Received: 20 April 2017 Accepted: 3 September 2017

Published online: 06 September 2017

\section{References}

1. Wechalekar AD, Gillmore JD, Hawkins PN. Systemic amyloidosis. Lancet. 2016;387:2641-54

2. Pepys MB. Amyloidosis. Annu Rev Med. 2006:57:223-41.

3. Lachmann HJ, Hawkins PN. Systemic amyloidosis. Curr Opin Pharmacol. 2006:6:214-20.

4. Merlini G. Systemic amyloidosis: are we moving ahead? Neth J Med. 2004; 62:104-5.

5. Dubrey SW, Hawkins PN, Falk RH. Amyloid diseases of the heart: assessment, diagnosis, and referral. Heart. 2011:97:75-84.

6. Falk RH. Cardiac amyloidosis: a treatable disease, often overlooked. Circulation. 2011;124:1079-85.

7. Dember LM. Amyloidosis-associated kidney disease. J Am Soc Nephrol. 2006:17:3458-71.

8. Gertz MA. The classification and typing of amyloid deposits. Am J Clin Pathol. 2004;121:787-9.

9. Rice L, Baker KR. Amyloidosis: changing approaches and outcomes. Methodist Debakey Cardiovasc J. 2012:8:2

10. Social Security System of Korea, National Health Insurance Service. http:// www.nhis.or.kr/static/html/wbd/g/a/wbdga0301.html. Accessed 1 Aug 2017.

11. Rothman KJ, Greenland S, Lash TL: Modern Epidemiology, 3rd edn. Philadelpia, USA: Lippincott Williams \& Winkins; 2008.

12. 2006 National Health Insurance Statistical Yearbook, Published by National Health Insurance Service; Health Insurance Review \& Assessment Service. http://www.nhis.or.kr/menu/boardRetriveMenuSet.xx?menuld=F3321. Accessed 1 Mar 2017.

13. 2007 National Health Insurance Statistical Yearbook, Published by National Health Insurance Service; Health Insurance Review \& Assessment Service. http://www.nhis.or.kr/menu/boardRetriveMenuSet.xx?menuld=F3321. Accessed 1 Mar 2017.

14. 2008 National Health Insurance Statistical Yearbook, Published by National Health Insurance Service; Health Insurance Review \& Assessment Service. http://www.nhis.or.kr/menu/boardRetriveMenuSet.xx?menuld=F3321. Accessed 1 Mar 2017.

15. 2009 National Health Insurance Statistical Yearbook, Published by National Health Insurance Service; Health Insurance Review \& Assessment Service. http://www.nhis.or.kr/menu/boardRetriveMenuSet.xx?menuld=F3321. Accessed 1 Mar 2017.

16. 2010 National Health Insurance Statistical Yearbook, Published by National Health Insurance Service; Health Insurance Review \& Assessment Service. http://www.nhis.or.kr/menu/boardRetriveMenuSet.xx?menuld=F3321. Accessed 1 Mar 2017

17. 2011 National Health Insurance Statistical Yearbook, Published by National Health Insurance Service; Health Insurance Review \& Assessment Service. http://www.nhis.or.kr/menu/boardRetriveMenuSet.xx?menuld=F3321. Accessed 1 Mar 2017.

18. 2012 National Health Insurance Statistical Yearbook, Published by National Health Insurance Service; Health Insurance Review \& Assessment Service. http://www.nhis.or.kr/menu/boardRetriveMenuSet.xx?menuld=F3321. Accessed 1 Mar 2017.

19. 2013 National Health Insurance Statistical Yearbook, Published by National Health Insurance Service; Health Insurance Review \& Assessment Service. http://www.nhis.or.kr/menu/boardRetriveMenuSet.xx?menuld=F3321. Accessed 1 Mar 2017.

20. 2014 National Health Insurance Statistical Yearbook, Published by National Health Insurance Service; Health Insurance Review \& Assessment Service. http://www.nhis.or.kr/menu/boardRetriveMenuSet.xx?menuld=F3321. Accessed 1 Mar 2017

21. 2015 National Health Insurance Statistical Yearbook, Published by National Health Insurance Service; Health Insurance Review \& Assessment Service. http://www.nhis.or.kr/menu/boardRetriveMenuSet.xx?menuld=F3321. Accessed 1 Mar 2017.

22. Census. Korean Statistical Information Service. http://kosis.kr/statisticsList/ statisticsList_01List.jsp?vwcd=MT_ZTITLE\&parentld=A (2016). Accessed 1 Mar 2017

23. Jang SY, Seo SR, Park SW, Kim DK. The prevalence of Marfan syndrome in Korea. J Korean Med Sci. 2017;32:576-80. 
24. Jang SY, Ju EY, Seo SR, Choi JY, Park SJ, Kim DK, Park SW. Changes in the etiology of valvular heart disease in the rapidly aging Korean population. Int J Cardiol. 2014;174:355-9.

25. Pinney JH, Smith CJ, Taube JB, Lachmann HJ, Venner CP, Gibbs SD, Dungu J, Banypersad SM, Wechalekar AD, Whelan CJ, et al. Systemic amyloidosis in England: an epidemiological study. Br J Haematol. 2013;161:525-32.

26. Narional Organizeation for Rare Disorder. https://rarediseases.org/rarediseases/amyloidosis/. Accessed 1 Apr 2017.

27. Ahmad OB, Cynthia BP, Lopez AD, Murray CJL, Lozano R, Inoue M: AGE STANDARDIZATION OF RATES:A NEW WHO STANDARD. EIP/GPE/EBD World Health Organization 2001 2001, GPE Discussion Paper Series: No.31:1-14.

Submit your next manuscript to BioMed Central and we will help you at every step:

- We accept pre-submission inquiries

- Our selector tool helps you to find the most relevant journal

- We provide round the clock customer support

- Convenient online submission

- Thorough peer review

- Inclusion in PubMed and all major indexing services

- Maximum visibility for your research

Submit your manuscript at www.biomedcentral.com/submit
Biomed Central 